\title{
Ten Reasons for IT Educators to be Early Adopters of IT Innovations
}

\section{Sharlett Gillard University of Southern Indiana, Evansville, IN, USA}

sgillard@usi.edu

\author{
Denice Bailey \\ Dickson County \\ School System, \\ Dickson, TN, USA
}

dbailey@dcbe.org

\author{
Ernest Nolan \\ University of \\ Southern Indiana, \\ Evansville, IN, USA
}

enolan@usi.edu

\section{Executive Summary}

Professionals in the information technology field are bombarded with an incessant stream of innovations in hardware and software as well as practices, methods, and techniques. IT educators are among the first targets in the market and must decide if and when to adopt these innovations in their instruction of students and professional endeavors. The risks are not small: educators must weigh the impact on budgets, time management schedules, instructional strategies, and student recompense. Some educators lag behind in adopting IT innovations and find that they have become pawns in the change process, vainly resisting the inevitable, while those on the front end of the adoption curve have eagerly embraced their role as change agents.

Various factors influence IT adoption among IT educators. Budget restraints, institutional resources, instructional support materials, timing, time, personal preferences, and personnel decisions (or lack thereof) are but a few of the many possible factors. It is not feasible, practical, nor prudent to adopt new technologies simply for the sake of adopting the "newest and latest". There are, however, numerous opportunities for the IT educator to choose whether to adopt an applicable IT innovation. It is that juncture (adopt or do not adopt) that is the topic of this article. When the various factors come together such that it is possible to adopt an applicable new IT product, some IT educators may elect to adopt while others may elect not to adopt. A number of theories have been proffered to explain the adoption decision, and models of adoption behavior have been created. We present ten reasons IT educators should adopt, as soon as feasible, applicable IT innovations introduced into the marketplace.

Reason 10, the sun came up today, denotes the universal consistency that exists not only in the physical world but also in our professional realm. The sun rises each day, and for the IT educator, change is inevitable. Change is often difficult and time consuming. However, it would seem to the authors that for most, the rewards would be worth the investment. Reason 9, you read the

Material published as part of this publication, either on-line or in print, is copyrighted by the Informing Science Institute. Permission to make digital or paper copy of part or all of these works for personal or classroom use is granted without fee provided that the copies are not made or distributed for profit or commercial advantage AND that copies 1) bear this notice in full and 2) give the full citation on the first page. It is permissible to abstract these works so long as credit is given. To copy in all other cases or to republish or to post on a server or to redistribute to lists requires specific permission and payment of a fee. Contact Publisher@InformingScience.org to request redistribution permission. obituaries and your name was not listed, indicates that resistance to change could lead to professional death.

Reason 8, there they go, and I must go after them, for I am their leader, emphasizes the enthusiasm with which many of our students embrace new technologies. They eagerly try each new gadget or gizmo and somehow anticipate that we, too, are familiar (or an expert) with the product. Perhaps we should not lag 
behind our students! Reason 7, if you can't run with the big dogs, stay on the porch, examines personal concerns, self identity, and "keeping up". Most IT educators seemingly believe that they are relatively up-to-date in the use and application of information technology. We should live up to our beliefs about ourselves.

Reason 6, life is good when you have the right tools for the job, reflects on the ever-changing "tools" and the quest for finding the "right" ones for a moving target! Reason 5, IT educators are by definition movers and shakers, posits that IT educators should be able to give students firsthand experience with new technologies and teach them the analytical skills they need to determine for themselves the potential of any given innovation.

Reason 4, someone is keeping score, points out that students, supervisors, peers, administrators, and industry watch and judge what we do as IT educators. Part of that judgment has to do with whether we "keep on top" of the latest technology. Reason 3, technology, technology, technology, highlights the rate of technology innovations and depicts the IT educator as a change agent, noting that change agents seek to secure the adoption of new ideas but may also attempt to slow the process and prevent the adoption of certain innovations with undesirable effects.

Reason 2, fulfilling the "leadership" role of higher education, speaks to the role that institutions of higher learning historically have sought to fulfill. Moreover it is the role expected by their community and their identified service area. The use of IT within academia has quickly become a benchmark by which academic institutions define their competitiveness, effectiveness, and leadership. Reason 1, setting the example for our students, challenges IT educators to demonstrate life-long learning skills as we examine new innovations, determine which are beneficial to our professional life and our students' futures, and adopt those that are appropriate.

Keywords: Information technology, IT innovations, technology adoption, IT educators, early adopters

\section{Introduction}

Innovations in the field of information technology (IT) continue to increase at an ever spiraling rate; advances in operating systems, software, communication devices and methodologies are renovating the inventory of IT products on a near daily basis. Businesses are embracing many of these technologies and are anticipating that university graduates will have the skills to quickly adapt to their business environment and choices of technologies. The IT educator plays a significant role in preparing students in IT fields of study to enter the IT-permeated business environment. That role is, in part, influenced by the educator's attitudes and choices regarding adoption of innovations. Educators in every discipline help to prepare their graduates for the world beyond the classroom. Every discipline has those educators who are considered "techies" or innovators those who are first to adopt new technologies. It is expected that a higher percentage of IT educators would be early adopters of IT innovations.

As new technology and changes to existing technologies make their way into the marketplace, those involved - private citizens, businesses, industry, and educational institutions - must determine the right time, if ever, to embrace these innovations and to integrate them into their lives and/or business processes or curricula. Not all consumers rush to buy a newly introduced product, and not all IT innovations are immediately embraced by IT professionals and educators. Ignoring the institutional and environmental influences that often hinder adoption (resource considerations), IT educators follow similar patterns of adoption as the population in general. Some tinker with virtually every new "toy" and adopt immediately those of interest or use; others wait for the innovators to sift out the chaff and then try only the "good stuff"; others wait until their friends, colleagues, or students are using and talking about a product and then decide they had better adopt just to fit in; others choose not to adopt and seem to wish they could go back to the 
"good 'ol days." Whereas few IT educators appear to fall into the "No, thank you!" category, by virtue of the nature of the field itself, the authors suggest that none should! There are numerous reasons. After a brief discussion of innovation adoption and diffusion theory as well as factors that influence an educator's adoption decision, ten reasons that support early adoption are presented.

\section{Innovation Adoption and Diffusion Theories}

Innovation adoption and diffusion theories as academic research endeavors have emerged over the last 40 or so years (McMaster \& Wastell, 2005), yielding numerous models: Theory of Planned Behavior (Ajzen, 1985); Technology Acceptance Model (Davis, 1986); Theory of Reasoned Action (Fishbein \& Ajzen, 1975); Concerns-Based Adoption Model (G. E. Hall, Wallace, \& Dossett, 1973); Technology-Adoption Life Cycle (Iowa State University, 1957); Instructional Transformation model (Rieber \& Welliver, 1989); Diffusion of Innovation (Rogers, 1962); Integrated Technology Adoption and Diffusion Model (Sherry, 1998); Decomposed Theory of Planned Behavior (Taylor \& Todd, 1995). Each model has a unique set of acceptance determinants (Venkatesh, Morris, Davis, \& Davis, 2003).

Research into the psychology of judgment and choice (Billings \& Scherer, 1988; Einhorn \& Hogarth, 1981; Kottermann \& Davis, 1991; Tversky, Sattath, \& Slovic, 1988; Zakay, 1985), sensemaking (Louis, 1980; Pereira, 2002; Prasad, 1993; Seligman, 2006; Weick, 1995;), and herd behavior (Banerjee, 1992; Farrell \& Saloner, 1985; Scharfstein \& Stein, 1990, 2000; Vergari, 2005) has enhanced the field of study and added unique dimensions to the research. Nay-sayers also enrich the field of research, provoking thought and entreating further research. McMaster and Wastell (2005, pg. 384), for example, contend that "diffusionism is a myth; its potency and pervasiveness derive not from any empirical validity but from its synergy with a colonialist mind-set, i.e. the generic aspiration of an elite few to gain power and influence over a subject community."

Researchers at Iowa State University (1957) developed the technology-adoption life cycle model, which has since been repeatedly applied and modified to describe adoption behavior for numerous application populations (Cravotta, 2003). Most of the adoption models depict five adopter categories - innovators, early adopters, early majority, late majority, and laggards - with relatively consistent characteristics among the derivative models (Geoghegan, 1994; Moore, 1991; Rogers, 1995).

M. Hall and Elliott (2003), building on models established by Geoghegan (1994) and Rogers (1983), applied the typology of adopters to faculty with regard to adoption of new instructional technology into the instructional process. As noted in the previous paragraph, the number of groups (5) was relatively consistent among the models. Where percentages were applied to the number of adopters, there was likewise relative consistency among models (Arnould, Price, \& Zinkhan, 2004; Berkowitz, Hartley, \& Rudelius, 2000). M. Hall and Elliott applied both the number of categories and percentages to faculty, identifying five groups of faculty members and associated characteristics that classify faculty by adopter category. Innovators are the first 3\% of all faculty members who adopt new instructional technology. They tend to be the campus "techies" who are intrigued by new hardware or software and are able to learn the new technology on their own. Early adopters represent the next $10 \%$ of faculty members to adopt an innovation and are viewed as visionaries or opinion leaders who combine their competence and desire in integrating new technologies into the classroom and teaching process. Typically the next $35 \%$ to adopt instructional technology, the early majority, are receptive to the technology but only after it has been shown to enhance teaching and student learning. The next 35\% to accept and use new instructional technology, the late majority, are skeptical and must be convinced or even coerced to use new technology in the classroom. The final $17 \%$ of faculty members to adopt innovative 
technologies, labeled the laggards, have absolutely no interest in using new technology in the classroom and may express opposition to its implementation.

In his seminal book, Diffusion of Innovations, first published in 1962 and now in its fifth edition, Rogers defines diffusion as "the process by which an innovation is communicated through certain channels over time among the members of a social system" (Rogers, 1983, pg. 5). Certainly one of the most successful diffusion tactics was the bundling of Microsoft's software with the purchase of a computer. Getting "free" software - indeed an entire suite of applications - enticed numerous buyers (adopters).

Rogers (1995) posits that certain characteristics of an innovation itself determine how quickly adoption will occur. These are relative advantage, compatibility, complexity, trialability, and observability. Relative advantage refers to the degree to which an innovation is perceived as better than the idea it supersedes. Compatibility is the degree to which an innovation is perceived as being consistent with the existing values, past experiences, and needs of potential adopters. Complexity is the degree to which an innovation is perceived as difficult to understand and use. Trialability is the degree to which a user may experiment with an innovation on a limited basis. Observability is the degree to which the results of an innovation are visible to others.

Innovations perceived as being only a small departure from current practices, as not too complex, that can be tried out before making a major commitment, and as compatible with current thinking will be adopted faster than their counterparts that require more thought or skill and cannot be easily observed Rogers (1995).

\section{Early Adoption Influences on IT Educators}

Innovation as used in this discussion refers to the prolific gizmos and gadgets continuously introduced to fascinate and/or aid the IT educator, the wide range of software to enhance professional and classroom productivity, creative ideas for delivery of classes, courses, and professional productivity, and other leading-edge breakthroughs for the IT educator. Or, as defined in marketing theory, "...new things and ideas and new ways of behaving and interacting with things" (Arnould et al., 2004, pg. 712) that pertain to the IT educator's professional life.

College and university educators in general and, for the purposes of this discussion, IT educators in particular have a unique set of personal values, motivators, organizational politics, and alliances that influence technology adoption decisions. Given the nature of their chosen field, most IT educators place value on creativity and learning. They have a wide range of external motivators but many are also self-motivators and risk-takers. But they also must function within the framework of their institution's philosophies, resources, and organizational, social, and political structure.

"Time management is a challenge that educators face on a daily basis. ... They need time to plan, time to prepare materials for the classroom, time for professional learning, time for record keeping, assessment and reporting, time to collaborate with their peers, time to develop interdisciplinary and differentiated instruction, and time for various duties and extracurricular activities. On top of this is the time teachers spend doing what they do best and love most: teaching." (Backhouse, 2003, pg. 5). The time demands of these activities should not be minimized. The seemingly straight-forward task of record keeping, for example, is often electronic and may require more time than expected when new versions of the software are introduced, when other hard/software changes affect the record keeping system, or when, for whatever reason, the electronic program or file is corrupted. Preparing for and attending professional conferences is often a significant time investment, and committee work can be overwhelming. 
Continually adopting "cutting-edge" technology strategies make yet another demand on faculty time. The multiplicity of duties required of faculty necessitates careful choices and prioritizing of values and motives. Keeping current with pedagogical advances and constantly changing business practices often seem to demand all of the time and energy a professor has to devote to professional activities. The ever shortening life cycle of technologies only increases the strain of trying to stay current. Training time alone, when added to existing time demands, could be sufficient to deter continual adoption of innovations. Some faculty view the tangible reward structure for teaching, research, and service obligations as either not requiring the integration of the latest technology or as carrying a significant negative risk should the technology not work properly, thus affecting their teaching evaluations and reputation. "Even when the technology works correctly, the integration of any new innovation into the classroom often presents unforeseen problems that can negatively affect the learning process" (McCorkle, Alexander \& Reardon, 2001, pg. 18).

Another factor influencing IT adoption is time in rank. Since most business faculty are not from the generation that grew up with personal computers and other hi-tech products, newly hired junior professors tend to incorporate IT to complement their teaching more frequently than senior professors (Bilmoria, 1999; McCorkle et al., 2001). Again, these observations are for business faculty in general and might be expected to be less pronounced, but not eliminated, among IT educators.

Institutional factors affecting IT adoption by faculty include time, money, support, and recognition. As an institutional factor, time refers to the demands placed on a professor's time as a contractual requirement of the job. Locating potential technologies, evaluating appropriateness, determining feasibility, planning for integration (into curricula, research or other activity), and implementation all take time. Institutions either deter or foster and encourage such activities by their position on issues such as providing release time for IT-related activities, teaching loads, number of class preps, class schedules, and committee and extracurricular requirements.

Technology adoption is likewise affected by the institution's commitment to and support level for IT initiatives with both finances and personnel. Everything costs money: hardware and software, peripheral equipment, sufficient support staff to troubleshoot and provide technical assistance, student assistants, professional-development opportunities, monetary incentives, travel support, research grants, and the many facets of university support services available from the library, academic computing, faculty development, and other campus organizations (Gilbert, 1995b, 1996; McCorkle et al., 2001; Seminoff \& Wepner, 1997; Spotts \& Bowman, 1997). Knowing that university support is/not available can certainly influence IT adoption decisions. Going a step further, knowing that the support personnel are available WHEN NEEDED is at least of equal importance to many. Unfortunately, "tech support is more likely focused on computer hardware and software needs within the labs and offices instead of on [IT] difficulties in the classrooms" (McCorkle et al., 2001, pg. 19).

IT adoption is likewise influenced by the university's incentive and reward structure for using and integrating technology in instruction. "Crimmel's (1984) observation, 'Hired to teach, but paid to publish,' presents a fairly accurate picture of the paradox facing most academics" (Lueddeke, 1999, pg. 240). To encourage IT adoption, annual reviews need to reflect and recognize the significant time investment by faculty who integrate new technologies into the curriculum. Release time, training opportunities, monetary rewards and non-monetary recognition, as well as tenure and promotion evaluation structures all have a bearing on IT adoption decisions.

Commitment to students must also weigh into IT adoption decisions. There is no question that technology skills will be essential in ever-increasing portions of the labor market. It is difficult to imagine a field or occupation in which IT does not play a significant role. "Consequently, col- 
leges and universities would be doing a major disservice to their students if they failed to provide appropriate opportunities to develop and enhance information technology skills as part of the undergraduate experience" (Green \& Gilbert, 1995, pg. 13). Professors must consider their role in providing students the exposure to IT that will prepare them for their chosen profession.

\section{So Why Be an Innovator or Early Adopter?}

With the sweeping changes in technology, educators in general must decide to be an "agent of change" or a "resistor of change." Were a poll of IT educators to be taken, the authors conclude from the previously-cited works that a majority of respondents would agree that IT educators should be innovators or early adopters and ahead of the technology curve rather than followers and behind the technology curve. Further, each educator in the above-posited poll would probably have his/her own list of the top ten reasons that IT educators (or, closer to home, why he/she) should be innovators or early adopters of IT innovations. Listed below, in reverse order, are the authors' top ten reasons for being an innovator or early adopter.

\section{The Sun Came Up Today}

There is probably nothing more predictable in the physical world in which we live than the sun rising and setting. In the professional world of information technology there is probably nothing more predictable than change itself. The IT product life cycle is becoming shorter and shorter, at an ever-increasing rate; and educators are being expected, even pressured, by multiple entities to keep pace and to recognize, evaluate, select, and adopt technological changes at the same everincreasing rate. Each IT educator has a choice to make: be a leader, a follower, or a resister. The pace may be exhausting, and fighting a current may sometimes be necessary, but as a general, relatively predictable practice, just as the sun came up today, we should welcome change, embrace it, learn to manage it, and be among the first to integrate it into our professional world.

Although once considered an unpredictable, instantaneous, and perhaps even random event, change is now seen as a somewhat predictable, manageable process (Surry \& Ensminger, 2006). Characteristic of any change, the adoption of innovations generally imposes a disruption of existing patterns of behavior. It may require educators to change teaching tools or methods, to interact with a different set of individuals, or to alter their outlook concerning pedagogical issues. Change is often difficult and time consuming. However, it would seem to the authors that for most, the rewards would be worth the investment.

\section{You Read the Obituaries and Your Name was Not Listed}

Sometimes just the fact that we are breathing is not enough to convince us that we are still alive and well in an ever-changing world. Individuals in this category may be resistant to change. Continued resistance, however, will almost certainly ensure an obsolete skill set and a resume that resides in the obituary section of one's chosen profession.

The ideological orientation of adoption research is that adoption of an innovation is desirable and failure to adopt is resistance (McMaster \& Wastell, 2005). McCorkle et al. (2001, pg. 18), while noting that laggards "lack either the time, resources, or inclination," proffers an underlying cause of non-adoption as "a systemic function of the reward structure within both the discipline and their current position that demands time and energy be spent in other endeavors." This is perhaps a more accurate description of IT faculty members who choose not to adopt a particular innovation. Yet another explanation is that they have judged the innovation and found it wanting.

A failure to adopt all innovations over an extended period of time, however, could be perceived as resisting rather than discerning or discriminating and lead to professional death. Selfpreservation and self-esteem are strong motivators, and those educators who are staying current 
with the train of IT developments - rather than waving as the caboose leaves the station - will bolster both.

\section{There They Go, and I Must Go After Them, for I Am Their Leader}

Most of our better students try the newest technological gadgets because they want to be "in with the in-crowd." The Internet is a plethora of pop-ups offering some new hi-tech gadget or gizmo to entertain, educate, or somehow improve life. Keeping up with the latest technology is just "cool" for our students, but it is an absolute necessity for IT instructors! Therefore if we as educators want to earn the respect of our students we must, at the very least, keep up.

$\mathrm{Hu}$ and Kuh (2001) noted that college-level students appear to use the internet to communicate with others and to find materials and assistance with their coursework. A casual survey of almost any senior level college classroom will reveal multiple other education-related uses from on-line purchases of textbooks, software, supplies, etc., to finding suitable housing to job searches and so much more. A 2003 study by the United States National Center for Education Statistics (NCES, 2006) reports a rapid rise in computer and internet usage by all kindergarten through grade 12 students over time as well as increased usage by younger-aged children. Disregarding the younger group, about 97 percent of children grades 9 - 12 were reported to use computers in 2003 and about 79 percent to use the internet. That was four years ago. Many from that population have either graduated from an institution of higher learning or are sitting in our classrooms today. Given the NCES statistics, we can only anticipate the percentages of students with pre-college computer and internet usage to increase.

We have all been in the situation at some time or another where someone in our class knew more about the subject we were teaching than we did. This can be a rewarding experience for teacher and student depending on "attitudes," or it can be most unpleasant. In any case, it is an uncomfortable situation that most of us would like to avoid. Keeping up with the latest trends in technology certainly increases our chances of keeping up with our students.

\section{If You Can't Run with the Big Dogs, Stay on the Porch}

"Concerns theory reports that at the early stages of [choosing and using] an innovation, teachers' concerns tend to be more personal. As personal concerns are resolved, teachers tend to be more concerned about the application (task and the impact of the innovation)" (Vaughan, 2002). The Stages of Concern (a measure of perceptions and feelings towards an innovation) dimension of the Concerns-Based Acceptance Model (G. E. Hall et al., 1973) purports that a teacher's concern about an innovation progresses in a predictable manner from awareness, through several stages (informational, personal, management, consequence, and collaboration) to refocusing. At the awareness level, the teacher is not involved with the change; at the refocusing stage, the teacher is skilled, experienced, and looking for ways to alter the existing innovation.

After a teacher has an awareness and has collected information concerning an innovation, personal issues dominate. Self-esteem, self-image, and "self-help" are motivating factors. Prasad (1993) found that IT adoption directly impacts identity construction. A technology user may consider himself or herself to be intelligent, cutting edge, aggressive, nerdy, professional, or other things, because he or she has or has not adopted technologies. Interestingly, perceived adoption by others may also affect a person's self-identity. For example, a person may consider himself or herself "cutting edge" until his or her co-worker obtains new equipment.

In this "dog eat dog" world, it is all about being out front: leadership. If you are not the lead dog, the view never changes and that alone is a very unpleasant thought. Reflecting on professional contacts, discussions, and feedback from conference sessions, it is the consensus of the authors 
that regardless of where we actually fit in the product adoption curve, most IT educators seemingly like to believe that they are relatively up-to-date in the use and application of information technology. It is time we live up to our beliefs about ourselves.

\section{Life is Good When You Have the Right Tools for the Job}

Ponder the age-old question, "How do you know when you have found the right software?" Over time everything changes, and the world of information technology is setting the pace. Settling in and getting comfortable with technology is the impossible dream. How many times have you thought to yourself, "Finally! The right balance of functionality and ease-of-use!" only to discover that, slowly but surely, compatibility issues with other hardware/software creep in and destroy your dream of the perfect relationship. Vendors sometimes "assist" in determining the right tool. A quite effective tactic of Microsoft and other vendors is the introduction of new versions of software with simultaneous, or at best soon thereafter, discontinued support of previous versions. For educators and others continuing to use that software, the decision to adopt the newer version, as well as when to adopt it, is virtually made for them.

Other tactics to entice a decision include trial offers, Beta versions, free CD's, education versions, on-line demos, etc. Educators' email accounts are often targets for notifications of new textbook titles as well as offerings for new hardware and software. Professional conferences are yet another source for "finding the right tool." Not only are vendors invited to display their wares, but educators present and discuss successes and failures with colleagues from other educational institutions in both formal and informal settings. Their presentations can trigger a trickle-down effect as others decide to climb aboard the bandwagon and adopt the reportedly successful innovations. In turn, the perception of the quality associated with the innovation increases as the number of adopters increases (Arnould et al., 2004).

If you resist change and hold on to the status quo for an extended time, you could end up under pressure from outside sources to adopt a newer technology quickly and find the process to be very painful. In other circumstances, holding off just a little in the adoption process may prove to be beneficial. Overall, however, keeping oneself a little closer to the front-end of the adoption curve would most probably reduce the overall stress level of dealing with information technology.

\section{IT Educators are by Definition Movers and Shakers}

The biggest separation or gap among faculty members in general with respect to acceptance and use of new instructional technology, according to Geoghegan (1994), is the gap between early adopters and the early majority. In fact, he posits that the separation is so large that in many cases the diffusion of new instructional technology is stymied at many colleges and universities. To help bridge this gap, he suggests among other things, that a "technologists' alliance" (early adopters and instructional technology personnel) be instituted to enhance the dissemination of information and provide peer support for the early majority. As leaders in the field, IT educators should accept that role, which includes setting the example.

With regard to our students, IT educators need no crystal ball to predict the future. We know that employers' reliance on IT and insistence on qualified, flexible employees with excellent criticalthinking skills will only increase. So as those who prepare students for a future in the field of information technology, we also should take our place in shaping the future for our students. We should be able to give students first-hand experience with new technologies and teach them the analytical skills they need to determine for themselves the potential of any given innovation. 


\section{Someone is Keeping Score}

Students are keeping score. For each course they take, students are usually invited or required to complete a course/faculty evaluation form. It is indisputable that one of the factors that influence students' evaluations is their perception of the educator's personality, as well as the educator's teaching ability and knowledge of the subject matter. Brennan, Miller, and Moniotte, (2001, pg 349) assert, "If adopting technology use will help to make faculty more flexible and open to change, and being more flexible and open to change will increase students' perceptions of faculty effectiveness, then adoption of technology will improve faculty course evaluations (if not their actual teaching!).”

Administrators are keeping score. If you are not a mover and shaker, and if you are not tenured, be prepared to be moved and shaken. IT innovations make the technology world a completely new field every few years, and those who do not keep up with the changes will eventually find that they do not know enough about their own field to educate their students. Educators who find themselves in the laggard category might as well spend time that should have been invested in the adoption process to begin looking for supplemental sources of income.

Industry is keeping score. Let's face it: even tenure does not protect IT educators from changes in the IT field. Nor does it blind the eyes of students who are looking for a top-notch program. Industry keeps a watch over universities to determine which schools offer more advanced IT programs. Students who are looking forward to future employment pay attention to industry preferences in relation to degree programs. When educators in a particular school build a reputation of being early adopters, industry notices, and this translates into potential students noticing as well. Industry scorecards cannot easily be ignored.

\section{Technology, Technology, Technology}

Technology is truly everywhere and its widespread adoption and application has changed the way each and every one of us lives and makes a living in modern society. Change is inevitable in life as well as in every profession; however, change in the information technology field is moving forward at a phenomenal rate. As educators and members of the information technology profession, we should not only embrace changes appropriate to our particular circumstances, but we should actually advance these changes by being "agents of change."

Innovators and early adopters often integrate emerging technologies into their courses even though on-site technological support is not always available. Often, these professors commit time, energy, and their own money based solely on a personal desire to learn the information, sometimes to the detriment of other dimensions of their job (McCorkle et al., 2001). Early adopters see technology as something they can use to enable "breakthrough improvements in teaching and learning" (Gilbert, 1995a, pg. 31).

Generally, change agents seek to secure the adoption of new ideas but may also attempt to slow the process and prevent the adoption of certain innovations with undesirable effects. Thus the change agent has several roles: identifying the need for change, establishing an informationexchange relationship, diagnosing problems, creating within the client the intent to change, translating intent to action, stabilizing adoption and preventing discontinuance, and achieving a terminal relationship. Change agents will be most effective if they can orient themselves toward their client [student] rather than their own agency [university] (Rogers, 1995).

\section{Fulfilling the "Leadership" Role of Higher Education}

Students and their families seek institutions that offer quality, economy, and efficiency. Employers need graduates who are technologically literate problem solvers and team players (Chisholm, 
Carey, \& Hernandez, 2002). Institutions of higher learning historically have sought to fulfill those needs while maintaining a well defined leadership role for their community and their identified service area. The use of IT within academia has quickly become a benchmark by which academic institutions define their competitiveness, effectiveness, and leadership (Henriksen \& Soule, 1998).

To maintain a leadership position it is important to be out front in the products and services adoption curve. Professors cannot bolster this leadership role as a "laggard." Sometimes it is uncomfortable on the "bleeding edge" of technology, but our role as educators in the information technology field dictates that we take on the role of an "innovator." This will allow us to exercise our leadership role and adopt applicable, feasible changes in technology before they have widespread acceptance in the business community. We should be ahead or with, but not behind, the organizations in which our students will find employment.

\section{Setting the Example for our Students}

Academia, not unlike other entities, has its own unique set of influences, politics, and values that drive decisions regarding adoption of innovations. When a particular innovation is available to academics, however, it often becomes an individual choice rather than an institutional choice to embrace or disregard the innovation. An individual's adoption decision can be summed up as "a function of available resources, the perceived value the individual ascribes to the innovation, and whether the individual engages in communication with other adopters" (Gilbert, 1995a, pg. 43). IT educators are inundated with new technologies; and though it might be easier to relax, pull out last year's materials, and conduct "business (class) as usual," it is important to stay focused on the task ahead: that of being an adopter - an early adopter - of applicable innovations and demonstrate by our actions that we practice what we teach.

One message we all hope that our students will take to heart is the concept of lifelong learning. In many institutions, promoting lifelong learning is a stated mission of the institution. It is of utmost importance that we set the proper example for our students and keep up with the latest trends within our information technology specialty. When innovative IT products are introduced into the market, we have an obligation to ourselves, our institution, our community, and our students to examine the products, embrace the changes, and incorporate appropriate innovations into the curriculum as soon as possible.

\section{Conclusion}

With the ever-increasing speed at which IT continues to advance, business, industry, educational institutions, and educators are placed in a precarious position. It is often a significant financial investment to adopt new technologies. It is likewise a significant time and energy investment for educators to adapt to and adopt new technologies, hardware, software, programming languages, books and teaching supplements, examples, exams, etc., etc. Most humans resist change and find a comfort zone in status quo. To adopt change for the sake of change is, however, inappropriate and inefficient. There are multiplicities of new technologies that ARE appropriate for IT educators, and thus IT educators should not succumb to complacency but accept their position of leadership and be among the early adopters of appropriate technologies: the $13 \%$ who are the agents of change in an ever-changing world.

\section{References}

Ajzen, I. (1985). From intentions to action: A theory of planned behavior. In J. Kuhl \& J. Beckman (Eds.), Action-control: From cognition to behaviors. New York: Springer.

Arnould, E., Price, L., \& Zinkhan, G. (2004). Consumers (2nd ed.). McGraw Hill Irwin. 
Backhouse, B. (2003). Information and communication technology integration: Beyond the early adopters. TechTrends, 47(3), 5-8.

Banerjee, A. V. (1992). A simple model of herd behavior. Quarterly Journal of Economics, 107(3) 797817.

Berkowitz, K., Hartley, \& Rudelius, (2000). Marketing (6th ed.). McGraw Hill Irwin.

Billings, R. S., \& Scherer, L. L. (1988). The effects of response mode and importance on decision-making strategies: Judgement versus choice. Organizational Behavior and Human Decision Processes, 41(1), $1-19$.

Bilmoria, D. (1999). Emerging technologies and management education. Journal of Management Education, 23(3), 229-232.

Brennan, L., Miller, J. R., \& Moniotte, S. M. (2001). Herding cats to water: Benchmarking the use of computers in business. Journal of Education for Business, 76(6), 345-352.

Chisholm, I. M., Carey, J., \& Hernandez, A. (2002). Information technology skills for a pluralistic society: Is the playing field level? Journal of Research on Technology in Education, 35(1), 58-79.

Cravotta, R. (2003). Welcome to the jungle. EDN, 48(24), 38-48.

Davis, F.D. (1986). A technology acceptance model for empirically testing new end-user information systems: Theory and results. Doctoral dissertation, Sloan School of Management, Massachusetts Institute of Technology.

Einhorn, H. J., \& Hogarth, R. M. (1981). Behavioral decision theory: Processes of judgment and choice. Annual Review of Psychology. 32, 53-88.

Farrell, J., \& Saloner, G. (1985). Standardization, compatibility, and innovation. The Rand Journal of Economics 16(1), 70-83.

Fishbein, M., \& Ajzen, I. (1975). Belief, attitude, intention, and behavior: An introduction to theory and research. Reading, MA: Addison-Wesley.

Geoghegan, W. H. (1994). What ever happened to instructional technology? Paper presented at the 22nd Annual Conference of the International Business Schools Computing Association. Baltimore, MD.

Gilbert, S. W. (1995a). An 'online' experience: Discussion group debates why faculty use or resist technology. Change, 27(2), 28-45.

Gilbert, S. W. (1995b). Teaching, learning, \& technology. Change, 27(2), 46-48.

Gilbert S. W. (1996). Making the most of a slow revolution. Change, 28(2), 10-27.

Green K. C., \& Gilbert, S. W. (1995). Great expectations. Change, 27(2), 8-18.

Hall, G. E., Wallace, R. C., \& Dossett, W. F. (1973). Procedures for adopting educational innovations. Austin, TX: The Research and Development Center for Teacher Education.

Hall, M., \& Elliott, K. M. (2003). Diffusion of technology into the teaching process: Strategies to encourage faculty members to embrace the laptop environment. Journal of Education for Business, 78(6), 301-307.

Henriksen J., \& Soule, A. (1998). Sources and information: Identifying and implementing technologies for higher education. New Directions for Community Colleges, 101 (spring), 91-98.

Hu, S., \& Kuh, G.D. (2001). Computing experience and good practices in undergraduate education: Does the degree of campus "wiredness" matter? Education Policy Analysis Archives, 9(49). Retrieved December 2, 2007 from http://epaa.asu.edu/epaa/v9n49.html

Iowa State University. (1957). The diffusion process. Special Report No. 18, 1957. Ames, IA: Agriculture Extension Service. 
Kottermann, J. E., \& Davis, F. D. (1991). Decisional conflict and user acceptance of multicriteria decisionmaking aids. Decision Sciences, 22(4), 918-926.

Louis, M. (1980). Surprise and sensemaking: What newcomers experience in entering unfamiliar organizational settings. Administrative Science Quarterly, 25(2), 226-51.

Lueddeke G. R. (1999). Toward a constructivist framework for guiding change and innovation in higher education. The Journal of Higher Education, 70(3), 235-260.

McCorkle, D. E., Alexander, J. F., \& Reardon, J. (2001). Integrating business technology and marketing education: Enhancing the diffusion process through technology champions. Journal of Marketing Education, 23(1), 16-25.

McMaster, T., \& Wastell, D. (2005). Diffusion - or delusion? Challenging an IS research tradition. Information Technology \& People, 18(4), 383-403.

Moore, G. (1991). Crossing the chasm. NY: HarperCollins.

National Center for Education Statistics (NCES), (2006). Computer and internet use by students in 2003. Retrieved December 2, 2007 from http://nces.ed.gov/pubsearch/pubsinfo.asp?pubid=2006065

Pereira, R. E. (2002). An adopter-centered approach to understanding adoption of innovations. European Journal of Innovation Management, 5(1), 40-50.

Prasad, P. (1993). Symbolic processes in the implementation of technological change: A symbolic interactionist study of work computerization. Academy of Management Journal, 36(6), 1400-1426.

Rieber, L. P., \& Welliver, P. W. (1989). Infusing educational technology into mainstream educational computing. Journal of Instructional Media, 16(1), 21-32.

Rogers, E. M. (1962). Diffusion of innovations, (1st ed.). The Free Press, New York, NY.

Rogers, E. M. (1983). Diffusion of innovations, (3rd ed.). The Free Press, New York, NY.

Rogers, E. M. (1995). Diffusion of innovations, (4th ed.). The Free Press, New York, NY.

Scharfstein, D., \& Stein, J. (1990). Herd behavior and investment. The American Economic Review, 80(3), 465-479.

Scharfstein, D., \& Stein, J. (2000). Herd behavior and investment: Reply. The American Economic Review, 90(3), 705-6.

Seligman, L. (2006). Sensemaking throughout adoption and the innovation-decision process. European Journal of Innovation Management, 9(1), 108-120.

Seminoff, N. E., \& Wepner, S. B. (1997). What should we know about technology-based projects for tenure and promotion? Journal of Research on Computing in Education, 30 (Fall), 67-82.

Sherry, L. (1998). An integrated technology adoption and diffusion model. International Journal of Educational Telecommunications, 4(2/3), 113-145.

Spotts, T., \& Bowman, M. A. (1997). Increasing faculty use of instructional technology: Barriers and incentives. EMI, 30(4), 199-204.

Surry, D. W., \& Ensminger, David C. (2006). Facilitating the use of web based learning by higher education faculty. Retrieved December 3, 2007, from

http://www.eric.ed.gov/ERICWebPortal/Home.portal?_nfpb=true\&ERICExtSearch_SearchValue_0=E $\underline{\text { nsmin- }}$ ger\&searchtype=keyword\&ERICExtSearch_SearchType_0=au\&_pageLabel=RecordDetails\&objectId $=0900019 \mathrm{~b} 800 \mathrm{f} 008 \mathrm{e} \& \mathrm{accno}=\mathrm{ED} 491622 \&$ nfls=false

Taylor, S., \& Todd, P. A. (1995). Understanding information technology usage: A test of competing models. Information Systems Research, 6(2), 144-176.

Tversky, A., Sattath, S., \& Slovic, P. (1988). Contingent weighting in judgment and choice. Research in Review, 95(3), 371-384. 
Vaughan, W. (2002). Professional development and the adoption and implementation of new innovations: Do teacher concerns matter? International Electronic Journal for Leadership in Learning, 6(5), Retrieved December 2, 2007, from http://www.ucalgary.ca/ iej1l/volume6/vaughan.html

Venkatesh, V., Morris, M. G., Davis, G. B., \& Davis, F. D. (2003). User acceptance of information technology: Toward a unified view. MIS Quarterly, 27(3), 425-478.

Vergari, C. (2005). Herd behavior in adoption of network technologies. Journal of Economics, 86(2), 161182.

Weick, K. (1995). Sensemaking in organizations. Thousand Oaks, CA: Sage.

Zakay, D. 1985). Post-decisional confidence and conflict experienced in a choice process. Acta Psychologica, 58(1), 75-80.

\section{Biographies}

Sharlett Gillard is a Professor of CIS, with emphasis in programming logic and languages as well as software applications. Dr. Gillard's research interests include curricular issues in CIS and human relations issues in project management.

Denice Bailey is a Language Arts teacher at Dickson Middle School in Dickson, Tennessee. She holds a B.A. in English and an M.Ed. She also has approximately 15 years of experience in advertising. Denice incorporates technology into her classroom teaching as often as possible, both on the administrative level and in practical experience through instruction and student hands-on experience.

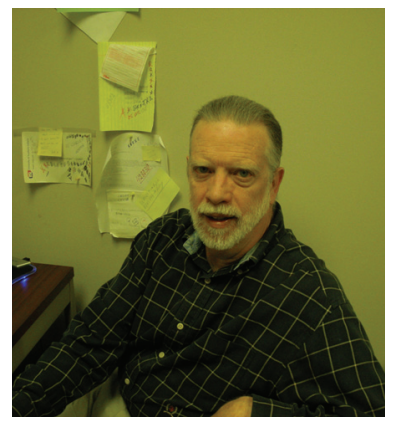

Ernest Nolan, Assistant Professor of CIS, teaches primarily systems analysis and design, applied software development (capstone senior project), programming logic, and programming languages. Ernest has many years of dedicated service in Association of Information Technology Professionals, having served as president at the Chapter, Region, and National levels. Under his guidance as faculty advisor, the USI student AITP chapter received the Student Chapter Outstanding Performance Award seventeen consecutive years. Ernest is also President of NCSD, Inc. which specializes in custom programming services for manufacturing firms and provides consulting services to numerous corporations, governmental units and not-for-profit organizations in IN, KY, and IL. 